[Regular Paper]

\title{
Effects of Support on Formation of Active Sites and Hydrodesulfurization Activity of Rhodium Phosphide Catalyst
}

\author{
Yasuharu KANDA $^{\dagger 1) *}$, Keisuke NAKatA ${ }^{\dagger 2)}$, Chisato TemmA ${ }^{\dagger 3)}$, Masatoshi SugiokA ${ }^{\dagger 4)}$, and Yoshio Uemichi ${ }^{\dagger 1)}$ \\ †1) Applied Chemistry Research Unit, College of Environmental Technology, Graduate School of Engineering, Muroran Institute of Technology, \\ 27-1 Mizumoto-cho, Muroran, Hokkaido 050-8585, JAPAN \\ ${ }^{\dagger 2)}$ Div. of Applied Chemistry, Graduate School of Engineering, Muroran Institute of Technology, \\ 27-1 Mizumoto-cho, Muroran, Hokkaido 050-8585, JAPAN \\ †3) Div. of Applied Sciences, Graduate School of Engineering, Muroran Institute of Technology, \\ 27-1 Mizumoto-cho, Muroran, Hokkaido 050-8585, JAPAN \\ †4) Aeronautics and Astronautics Unit, College of Design and Manufacturing Technology, Graduate School of Engineering, \\ Muroran Institute of Technology, 27-1 Mizumoto-cho, Muroran, Hokkaido 050-8585, JAPAN
}

(Received August 8, 2011)

\begin{abstract}
The effects of the support on active site formation and hydrodesulfurization (HDS) activity of $\mathrm{Rh}_{2} \mathrm{P}$ catalyst were examined, using metal oxides $\left(\mathrm{MO}_{x}\right)$, such as $\mathrm{SiO}_{2}, \mathrm{TiO}_{2}, \mathrm{Al}_{2} \mathrm{O}_{3}, \mathrm{MgO}$ and $\mathrm{ZrO}_{2}$, as the support. $\mathrm{Rh}_{2} \mathrm{P}$ was formed on $\mathrm{MO}_{x}$ support after reduction of supported rhodium and phosphorus $(\mathrm{Rh}-\mathrm{P})$ catalysts. However, differences in the formation temperatures of $\mathrm{Rh}_{2} \mathrm{P}$ were observed by changing the $\mathrm{MO}_{x}$ support. Furthermore, the HDS activities of the supported Rh-P catalysts strongly changed with higher reduction temperature. The order of HDS activities of Rh-P/MO $/ \mathrm{MO}_{x}$ catalysts reduced at optimal temperatures was $\mathrm{SiO}_{2} \sim \mathrm{TiO}_{2} \sim \mathrm{Al}_{2} \mathrm{O}_{3}>\mathrm{MgO}>$ $\mathrm{ZrO}_{2}$. The TOF of $\mathrm{Rh}-\mathrm{P} / \mathrm{MO}_{x}$ catalysts was enhanced by increasing the reduction temperature to form $\mathrm{Rh}_{2} \mathrm{P}$. The order of TOF of supported $\mathrm{Rh}_{2} \mathrm{P}$ catalysts was $\mathrm{TiO}_{2}>\mathrm{ZrO}_{2}>\mathrm{Al}_{2} \mathrm{O}_{3}>\mathrm{SiO}_{2}>\mathrm{MgO}$, and this order disagreed with that of thiophene conversion. The high TOF of $\mathrm{Rh}-\mathrm{P} / \mathrm{TiO}_{2}$ catalyst may be explained by formation of partially sulfided $\mathrm{TiO}_{2}$ in the HDS reaction. The low $\mathrm{TOF}$ of $\mathrm{Rh}-\mathrm{P} / \mathrm{MgO}$ catalyst was attributed to the basicity of the support with low sulfur tolerance.
\end{abstract}

\section{Keywords}

Rhodium phosphide catalyst, Metal oxide support, Hydrodesulfurization, Thiophene

\section{Introduction}

Hydrodesulfurization (HDS) is one of the most important processes used in the petroleum industry for the production of clean fuels which prevent acid rain and deactivation of automotive exhaust catalysts. $\mathrm{CoMo} / \mathrm{Al}_{2} \mathrm{O}_{3}$ catalysts have been widely used in the HDS process. In the past decade, regulation of the sulfur contents of gasoline and diesel fuel in Japan has become significantly more severe. In the near future, regulation of sulfur oxides $\left(\mathrm{SO}_{x}\right)$ emission from ships will be stricter, because fuels for ships contain larger amounts of sulfur compounds compared with gasoline and diesel fuel. Therefore, the petroleum industry is depending on the development of highly active HDS catalysts to produce cleaner fuels.

The preparation of highly active CoMo-based HDS catalysts has been widely investigated, such as Timodification of $\mathrm{Al}_{2} \mathrm{O}_{3}$ support ${ }^{1)}$, Co-CVD technique ${ }^{2), 3)}$,

\footnotetext{
* To whom correspondence should be addressed.

* E-mail: kanda@mmm.muroran-it.ac.jp
}

and addition of chelating agents ${ }^{4), 5)}$, citric acid ${ }^{6}$ and phosphorus ${ }^{3), 7), 8)}$. Furthermore, new active phases, not sulfided CoMo catalysts, have been reported by many researchers. Noble metals ${ }^{9) \sim 14)}$, transition metal carbides $^{15) \sim 17)}$, nitrides ${ }^{15), 18)}$ and phosphides ${ }^{19) \sim 26)}$ have been employed as new HDS catalysts. Transition metal phosphides, such as $\mathrm{Ni}_{2} \mathrm{P}^{19) \sim 24)}$ and $\mathrm{MoP}^{25) \sim 28)}$, have received much attention as new HDS catalysts. In particular, $\mathrm{Ni}_{2} \mathrm{P}$ catalyst has high potential for the HDS reaction. On the other hand, we have reported that noble metal phosphides, especially rhodium phosphide $\left(\mathrm{Rh}_{2} \mathrm{P}\right)$, supported on $\mathrm{SiO}_{2}$ have high and stable catalytic activity for the HDS of thiophene ${ }^{29)}$. Furthermore, Bussell et al. reported that $\mathrm{Rh}_{2} \mathrm{P} / \mathrm{SiO}_{2}$ catalyst has high activity for the HDS of dibenzothiophene ${ }^{30)}$. However, the effect of the support on the HDS activity of $\mathrm{Rh}_{2} \mathrm{P}$ catalyst remains unknown. The support affects the HDS activity of CoMo catalyst ${ }^{31)}$ and the acidity of the support enhances the sulfur tolerance of noble metalbased HDS catalyst ${ }^{32) ~ 34)}$. Since $\mathrm{AlPO}_{4}$ inhibits formation of $\mathrm{Ni}_{2} \mathrm{P}, \mathrm{Al}_{2} \mathrm{O}_{3}$ is not suitable as a support for $\mathrm{Ni}_{2} \mathrm{P}$ catalyst ${ }^{22}$. Therefore, the effects of the support 
on the formation and catalytic activity of $\mathrm{Rh}_{2} \mathrm{P}$ for the HDS reaction require investigation.

The present study examined the effect of metal oxide $\left(\mathrm{MO}_{x}\right)$ support on phosphidation of Rh species to form active sites and the HDS activity of supported $\mathrm{Rh}_{2} \mathrm{P}$ catalyst.

\section{Experimental}

\section{1. Preparation of Catalysts}

We used $\mathrm{MO}_{x}$, such as silica $\left(\mathrm{SiO}_{2}\right)$, alumina $\left(\mathrm{Al}_{2} \mathrm{O}_{3}\right)$, titania $\left(\mathrm{TiO}_{2}\right)$, magnesia $(\mathrm{MgO})$ and zirconia $\left(\mathrm{ZrO}_{2}\right)$, as supports. The $\mathrm{Rh} / \mathrm{MO}_{x}$ catalysts were prepared by an impregnation method using aqueous solution of rhodium (III) chloride trihydrate $\left(\mathrm{RhCl}_{3} \cdot 3 \mathrm{H}_{2} \mathrm{O}\right)$. The amount of $\mathrm{Rh}$ loading was 5 mass\%. Impregnated catalysts were dried at $110{ }^{\circ} \mathrm{C}$ for $24 \mathrm{~h}$ followed by heat treatment in a nitrogen stream at $450{ }^{\circ} \mathrm{C}$ for $1 \mathrm{~h}$ to decompose the salt. The supported Rh catalysts were then pressed into disks and crushed to obtain 30-42 mesh size granules. The sieved catalysts were calcined in air at $500{ }^{\circ} \mathrm{C}$ for $4 \mathrm{~h}$. The increase rate of heat treatment and calcination was $10{ }^{\circ} \mathrm{C} \cdot \mathrm{min}^{-1}$. $\quad \mathrm{P}$-added $\mathrm{Rh}(\mathrm{Rh}-\mathrm{P})$ catalysts were prepared by the same procedure using $\mathrm{RhCl}_{3} \cdot 3 \mathrm{H}_{2} \mathrm{O}$ and ammonium dihydrogen phosphate $\left(\mathrm{NH}_{4} \mathrm{H}_{2} \mathrm{PO}_{4}\right)$ aqueous solutions. The amount of $\mathrm{P}$ addition was 1.5 mass $\%$.

\section{2. Characterization of Catalysts}

Supported $\mathrm{Rh}$ and $\mathrm{Rh}-\mathrm{P}$ catalysts were characterized by temperature-programmed reduction (TPR), X-ray diffraction (XRD), and BET surface area and CO adsorption measurements. TPR spectra were measured using a Shimadzu GC-8A gas chromatograph. Supported Rh or Rh-P catalysts $(0.1 \mathrm{~g})$ were heated in a helium stream $\left(30 \mathrm{~mL} \cdot \mathrm{min}^{-1}\right)$ from room temperature to $500{ }^{\circ} \mathrm{C}$ at $10{ }^{\circ} \mathrm{C} \cdot \mathrm{min}^{-1}$, followed by heating at $500{ }^{\circ} \mathrm{C}$ for $1 \mathrm{~h}$ in helium. The calcined catalysts were then cooled to $30{ }^{\circ} \mathrm{C}$ in a helium stream, and the helium was switched to 5 vol\% hydrogen-nitrogen $\left(\mathrm{H}_{2}-\mathrm{N}_{2}\right)$ gas mixture at $30{ }^{\circ} \mathrm{C}$ for $30 \mathrm{~min}$ before measurement. Water was removed with a molecular sieve trap. The TPR spectra were recorded through the range from 30 to $850{ }^{\circ} \mathrm{C}$ at $10{ }^{\circ} \mathrm{C} \cdot \mathrm{min}^{-1}$, using a thermal conductivity detector (TCD) to monitor hydrogen consumption. XRD patterns of calcined and reduced catalysts were measured by a Rigaku MiniFlex with $\mathrm{Cu} \mathrm{K} \alpha$ radiation at $30 \mathrm{kV}$ and $15 \mathrm{~mA}$. Crystallite sizes of $\mathrm{Rh}$ and $\mathrm{Rh}_{2} \mathrm{P}$ were calculated by Scherrer's equation. Measurement of BET surface area was carried out using a Micromeritics ASAP 2010. The catalysts were evacuated at $300{ }^{\circ} \mathrm{C}$ for $5 \mathrm{~h}$ before nitrogen adsorption at $-196{ }^{\circ} \mathrm{C}$. CO adsorption on supported Rh and Rh-P catalysts was measured using the pulse method. Supported $\mathrm{Rh}$ or $\mathrm{Rh}-\mathrm{P}$ catalysts $(0.1 \mathrm{~g})$ were treated in helium at $500{ }^{\circ} \mathrm{C}$ (heating rate: $10{ }^{\circ} \mathrm{C} \cdot \mathrm{min}^{-1}$ ) for $1 \mathrm{~h}$, followed by reduction in hydrogen at $350-850{ }^{\circ} \mathrm{C}$ for
1 h. CO was injected onto the catalyst layer at $25{ }^{\circ} \mathrm{C}$ using the sampling loop. The amount of $\mathrm{CO}$ adsorbed was measured with a Shimadzu GC-8A gas chromatograph equipped with a TCD.

\section{3. Hydrodesulfurization of Thiophene}

HDS of thiophene was performed at $350{ }^{\circ} \mathrm{C}$ under $0.1 \mathrm{MPa}$ using a conventional fixed bed flow reactor. The catalyst $(0.1 \mathrm{~g})$ was charged into the quartz reactor and was heated $\left(10^{\circ} \mathrm{C} \cdot \mathrm{min}^{-1}\right)$ in a helium stream $\left(30 \mathrm{~mL} \cdot \mathrm{min}^{-1}\right)$ to $500{ }^{\circ} \mathrm{C}$ and heated for $1 \mathrm{~h}$. After helium treatment, the catalyst was reduced under hydrogen $\left(30 \mathrm{~mL} \cdot \mathrm{min}^{-1}\right)$ at $350-850{ }^{\circ} \mathrm{C}$ for $1 \mathrm{~h}$. Hydrogenthiophene gas mixture $\left(\mathrm{H}_{2} / \mathrm{C}_{4} \mathrm{H}_{4} \mathrm{~S}=30\right)$, obtained by passing a hydrogen stream through a thiophene trap cooled at $0{ }^{\circ} \mathrm{C}$, was introduced into the reactor. The reaction condition $(W / F)$ was $37.9 \mathrm{~g} \cdot \mathrm{h} \cdot \mathrm{mol}^{-1}$. The reaction products were analyzed with a gas chromatograph (FID) equipped with silicone DC-550 (2 m, $\left.135^{\circ} \mathrm{C}\right)$ and VZ-7 $\left(4 \mathrm{~m}, 0{ }^{\circ} \mathrm{C}\right)$ columns. Commercial $\mathrm{CoMoP} / \mathrm{Al}_{2} \mathrm{O}_{3}$ (Co: 2.5 mass\%, Mo: 10.0 mass\% and $\mathrm{P}$ : 2.1 mass \%) catalyst was used to assess the supported $\mathrm{Rh}-\mathrm{P}$ catalysts. Pre-sulfided $\mathrm{CoMoP} / \mathrm{Al}_{2} \mathrm{O}_{3}$ catalyst was prepared using $5 \mathrm{vol} \%$ hydrogensulfide-hydrogen $\left(\mathrm{H}_{2} \mathrm{~S}-\mathrm{H}_{2}\right)$ at $400{ }^{\circ} \mathrm{C}$ after hydrogen reduction at $450{ }^{\circ} \mathrm{C}$.

\section{Results and Discussion}

\section{1. Effect of Reduction Temperature on Formation of $R_{2} P$}

\section{1. 1. XRD Patterns of Calcined $R h$ and $R h-P$ Catalysts}

To analyze the Rh species after calcination, the XRD patterns of $\mathrm{MO}_{x}$-supported $\mathrm{Rh}$ and $\mathrm{Rh}-\mathrm{P}$ catalysts were observed. Figures $\mathbf{1}$ and $\mathbf{2}$ show the XRD patterns of supported $\mathrm{Rh}$ and $\mathrm{Rh}-\mathrm{P}$ catalysts after calcination at $500{ }^{\circ} \mathrm{C}$, respectively. The peak of $\mathrm{Rh}_{2} \mathrm{O}_{3}\left(2 \theta=34.2^{\circ}\right)$ appeared on the XRD patterns of $\mathrm{Rh} / \mathrm{SiO}_{2}$ (Fig. 1 (i), (b)), $\mathrm{Rh}-\mathrm{P} / \mathrm{SiO}_{2}$ (Fig. 2 (i), (b)) and $\mathrm{Rh}-\mathrm{P} / \mathrm{TiO}_{2}$ (Fig. 2 (iii), (b)). However, this peak was not observed in the XRD patterns of $\mathrm{Rh}$ and $\mathrm{Rh}-\mathrm{P}$ supported on $\mathrm{Al}_{2} \mathrm{O}_{3}$ (Figs. 1 and 2 (ii), (b)) and $\mathrm{MgO}$ (Figs. 1 and 2 (iv), (b)) indicating that the Rh species were highly dispersed on $\mathrm{MgO}$ and $\mathrm{Al}_{2} \mathrm{O}_{3}$ supports. Since the XRD pattern of $\mathrm{Rh} / \mathrm{ZrO}_{2}$ catalyst (Fig. 1 (v), (b)) showed no peaks of $\mathrm{Rh}$ or $\mathrm{Rh}_{2} \mathrm{O}_{3}$, $\mathrm{Rh}$ species were highly dispersed on $\mathrm{ZrO}_{2}$ support. On the other hand, the XRD pattern of $\mathrm{Rh}-\mathrm{P} /$ $\mathrm{ZrO}_{2}$ included the peaks of metallic Rh (Fig. 2 (v), (b)), indicating that most large $\mathrm{Rh}$ particles formed after salt decomposition were not oxidized by calcination at $500{ }^{\circ} \mathrm{C}$.

\section{1. 2. TPR Spectra of $R h$ and $R h-P$ Catalysts}

The TPR spectra of $\mathrm{MO}_{x}$-supported $\mathrm{Rh}$ and $\mathrm{Rh}-\mathrm{P}$ catalysts were examined to obtain information about $\mathrm{Rh}_{2} \mathrm{P}$ formation. The TPR spectra of supported Rh catalysts are shown in Fig. 3. The TPR spectra of $\mathrm{MO}_{x}$ support (a) included a small hydrogen consumption peak at 

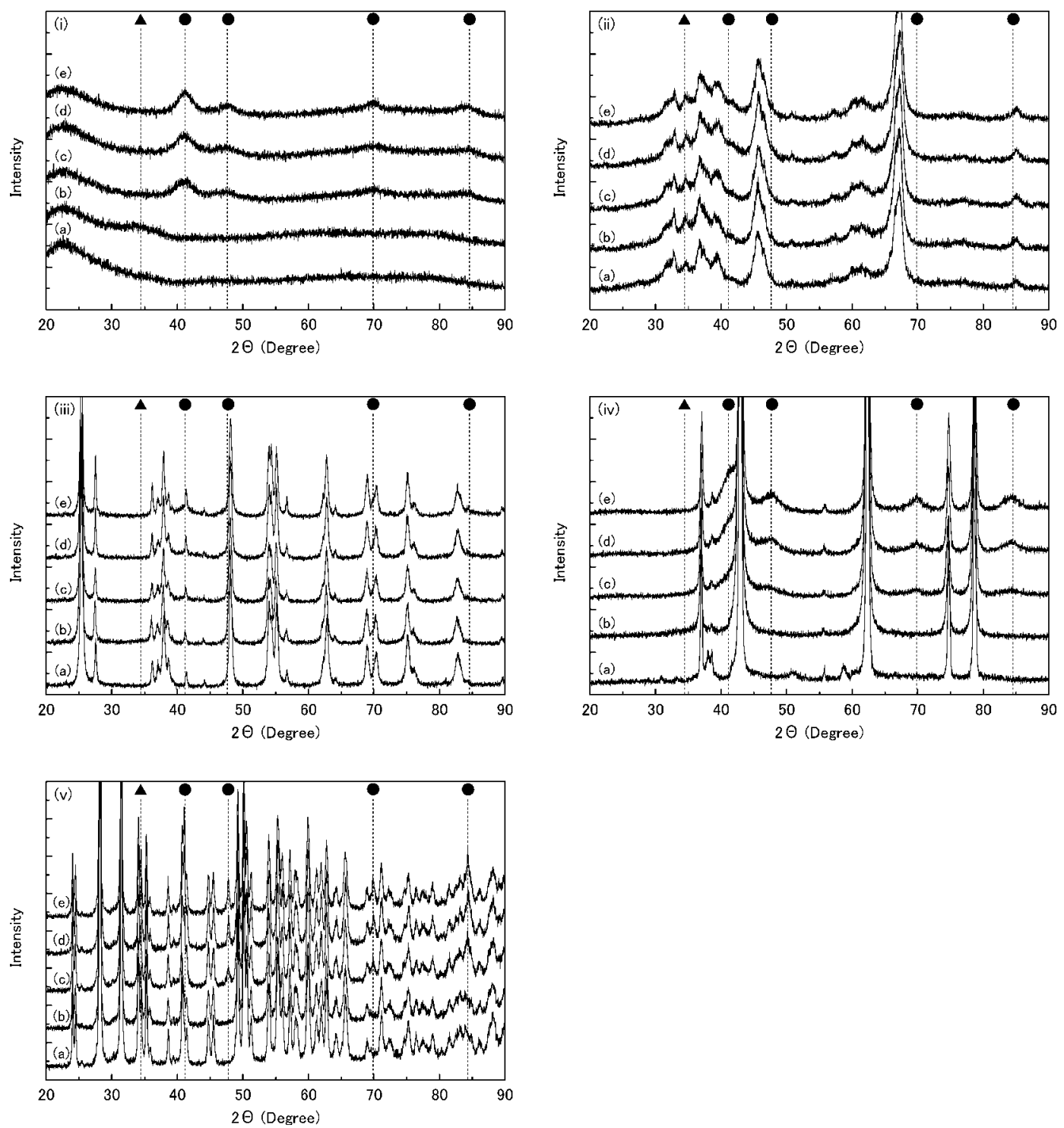

Support: (i) $\mathrm{SiO}_{2}$, (ii) $\mathrm{Al}_{2} \mathrm{O}_{3}$, (iii) $\mathrm{TiO}_{2}$, (iv) $\mathrm{MgO}$, (v) $\mathrm{ZrO}_{2}$.

(a) Support, (b) Calcined at $500{ }^{\circ} \mathrm{C}$, Reduced at (c) $450{ }^{\circ} \mathrm{C}$, (d) $550{ }^{\circ} \mathrm{C}$, (e) $650{ }^{\circ} \mathrm{C}$.

А : $\mathrm{Rh}_{2} \mathrm{O}_{3}, \mathbf{O}: \mathrm{Rh}$.

Fig. 1 XRD Patterns of Calcined and Reduced Rh Catalysts

$550{ }^{\circ} \mathrm{C}$ for $\mathrm{TiO}_{2}$ (iii) and $600{ }^{\circ} \mathrm{C}$ for $\mathrm{ZrO}_{2}(\mathbf{v})$. However, no such peaks appeared in spectra of other $\mathrm{MO}_{x}$ supports. These results show that $\mathrm{TiO}_{2}$ and $\mathrm{ZrO}_{2}$ are reducible in contrast to the other supports. The peaks attributed to the reduction of $\mathrm{Rh}_{2} \mathrm{O}_{3}$ were observed around 50 to $150{ }^{\circ} \mathrm{C}$ in the spectra of $\mathrm{Rh} / \mathrm{MO}_{x}$ catalysts (b). On the other hand, a peak around $450{ }^{\circ} \mathrm{C}$ was also observed in the spectra of $\mathrm{Rh} / \mathrm{MgO}$ ((iv), (b)), which was attributed to the reduction of $\mathrm{MgRh}_{2} \mathrm{O}_{4}{ }^{35)}$. However, the diffraction peaks of $\mathrm{MgRh}_{2} \mathrm{O}_{4}(2 \theta=29.7$, 35.0 and $52.7^{\circ}$ ) were not observed in the XRD pattern of calcined $\mathrm{Rh} / \mathrm{MgO}$, as shown in Fig. 1 (iv), (b). These results indicate that highly dispersed $\mathrm{MgRh}_{2} \mathrm{O}_{4}$ was present in the $\mathrm{Rh} / \mathrm{MgO}$ catalyst. Furthermore, the spectrum of $\mathrm{Rh} / \mathrm{TiO}_{2}$ catalyst ((iii), (b)) contained a broad peak around $650{ }^{\circ} \mathrm{C}$, which was attributed to reduction of the support. The TPR spectra of Rh-P/MO catalysts are shown in Fig. 3. The peak of $\mathrm{Rh}_{2} \mathrm{O}_{3}$ reduction at 50 to $150{ }^{\circ} \mathrm{C}$ was also observed in all $\mathrm{Rh}^{-} \mathrm{P}$ catalysts, except for the $\mathrm{MgO}$ support. Moreover, the reduction peaks of phosphates were observed in the spectra of $\mathrm{Rh}-\mathrm{P}$ catalysts.

However, the peak temperature attributed to phosphate reduction was remarkably changed by the type of $\mathrm{MO}_{x}$ support. In the spectrum of $\mathrm{Rh}-\mathrm{P} / \mathrm{SiO}_{2}((\mathbf{i}),(\mathrm{c}))$, broad peaks appeared at 270,360 and $650{ }^{\circ} \mathrm{C}$. Formation of $\mathrm{Rh}_{2} \mathrm{P}$ from rhodium phosphate by hydrogen reduction is reported to occur at $350{ }^{\circ} \mathrm{C}^{36}$. Thus, 

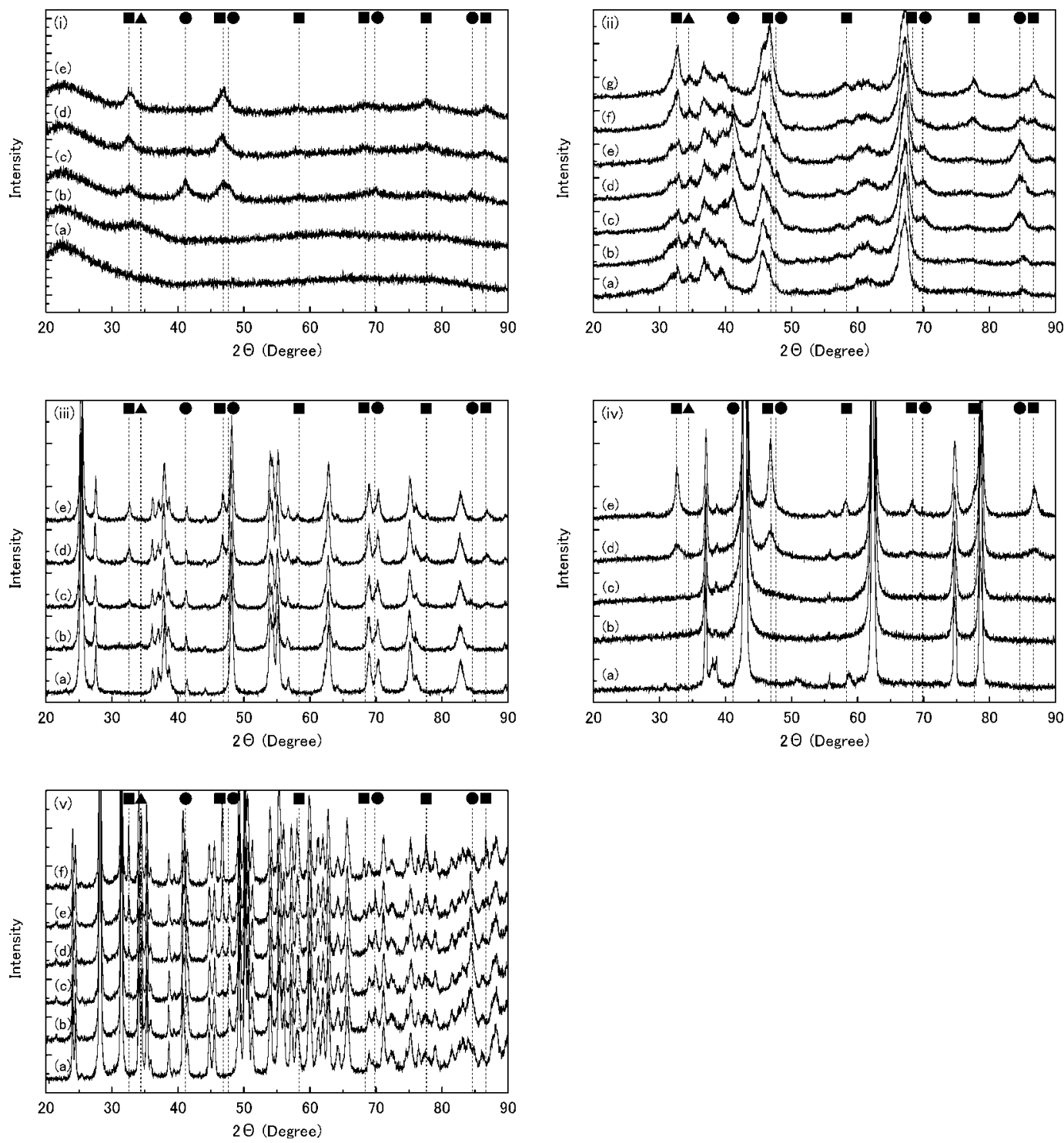

Support: (i) $\mathrm{SiO}_{2}$, (ii) $\mathrm{Al}_{2} \mathrm{O}_{3}$, (iii) $\mathrm{TiO}_{2}$, (iv) $\mathrm{MgO}$, (v) $\mathrm{ZrO}_{2}$.

(a) Support, (b) Calcined at $500{ }^{\circ} \mathrm{C}$, Reduced at (c) $450{ }^{\circ} \mathrm{C}$, (d) $550{ }^{\circ} \mathrm{C}$, (e) $650{ }^{\circ} \mathrm{C}$, (f) $750{ }^{\circ} \mathrm{C}$, (g) $850{ }^{\circ} \mathrm{C}$.

А: $\mathrm{Rh}_{2} \mathrm{O}_{3}, \mathbf{O}: \mathrm{Rh}, \mathbf{\square}: \mathrm{Rh}_{2} \mathrm{P}$.

Fig. 2 XRD Patterns of Calcined and Reduced Rh-P Catalysts

the peak at $360{ }^{\circ} \mathrm{C}$ was attributed to the reduction of phosphates to form $\mathrm{Rh}_{2} \mathrm{P}$. The spectrum of $\mathrm{Rh}-\mathrm{P} / \mathrm{TiO}_{2}$ ((iii), (c)), contained peaks at 280,540 and $730{ }^{\circ} \mathrm{C}$, and a shoulder peak appeared at $400{ }^{\circ} \mathrm{C}$. This trend was the same as that observed for $\mathrm{Rh}-\mathrm{P} / \mathrm{SiO}_{2} . \quad \mathrm{TiO}_{2}$ is well known to be more reducible than other metal oxides $^{37), 38)}$. Thus, the large peak observed at $540{ }^{\circ} \mathrm{C}$ would be attributed to the reduction of phosphate and $\mathrm{TiO}_{2}$ support. The spectrum of $\mathrm{Rh}-\mathrm{P} / \mathrm{Al}_{2} \mathrm{O}_{3}$ catalyst ((ii), (c)), contained no peaks from 200 to $600{ }^{\circ} \mathrm{C}$, but hydrogen consumption increased above $700{ }^{\circ} \mathrm{C}$. This observation indicates that $\mathrm{Rh}_{2} \mathrm{P}$ is difficult to form on $\mathrm{Al}_{2} \mathrm{O}_{3}$ compared with $\mathrm{SiO}_{2}$ and $\mathrm{TiO}_{2}$. The peak temperature in the TPR spectra of $\mathrm{MoP} / \mathrm{Al}_{2} \mathrm{O}_{3}$ occurred at about 800 to $900{ }^{\circ} \mathrm{C}^{27)}$, higher than that observed for $\mathrm{MoP} / \mathrm{SiO}_{2}\left(550{ }^{\circ} \mathrm{C}\right)^{25)}$. Furthermore, phosphorus reacts with the surface of $\mathrm{Al}_{2} \mathrm{O}_{3}$ to form $\mathrm{AlPO}_{4}$ in $\mathrm{Ni}_{2} \mathrm{P} /$ $\mathrm{Al}_{2} \mathrm{O}_{3}$ catalyst ${ }^{22}$. Thus, the peak observed at higher temperature in the TPR spectrum of $\mathrm{Rh}-\mathrm{P} / \mathrm{Al}_{2} \mathrm{O}_{3}$ was attributed to the reduction of $\mathrm{AlPO}_{4}$ to form $\mathrm{Rh}_{2} \mathrm{P}$. The same trend was also observed in the TPR spectrum of $\mathrm{Rh}-\mathrm{P} / \mathrm{ZrO}_{2}((\mathbf{v}),(\mathrm{c}))$ indicating that formation of $\mathrm{Rh}_{2} \mathrm{P}$ is difficult on $\mathrm{Al}_{2} \mathrm{O}_{3}$ and $\mathrm{ZrO}_{2}$ supports. On the other hand, the reduction peak of $\mathrm{MgRh}_{2} \mathrm{O}_{4}$ also appeared at $550{ }^{\circ} \mathrm{C}$ in the spectrum of $\mathrm{Rh}-\mathrm{P} / \mathrm{MgO}$ catalyst ((iv), (c)). Furthermore, no peaks of Rh species were found in the XRD pattern of $\mathrm{Rh}-\mathrm{P} / \mathrm{MgO}$ catalyst after calcination, as shown in Fig. 2 (iv), (b). This result shows that highly 

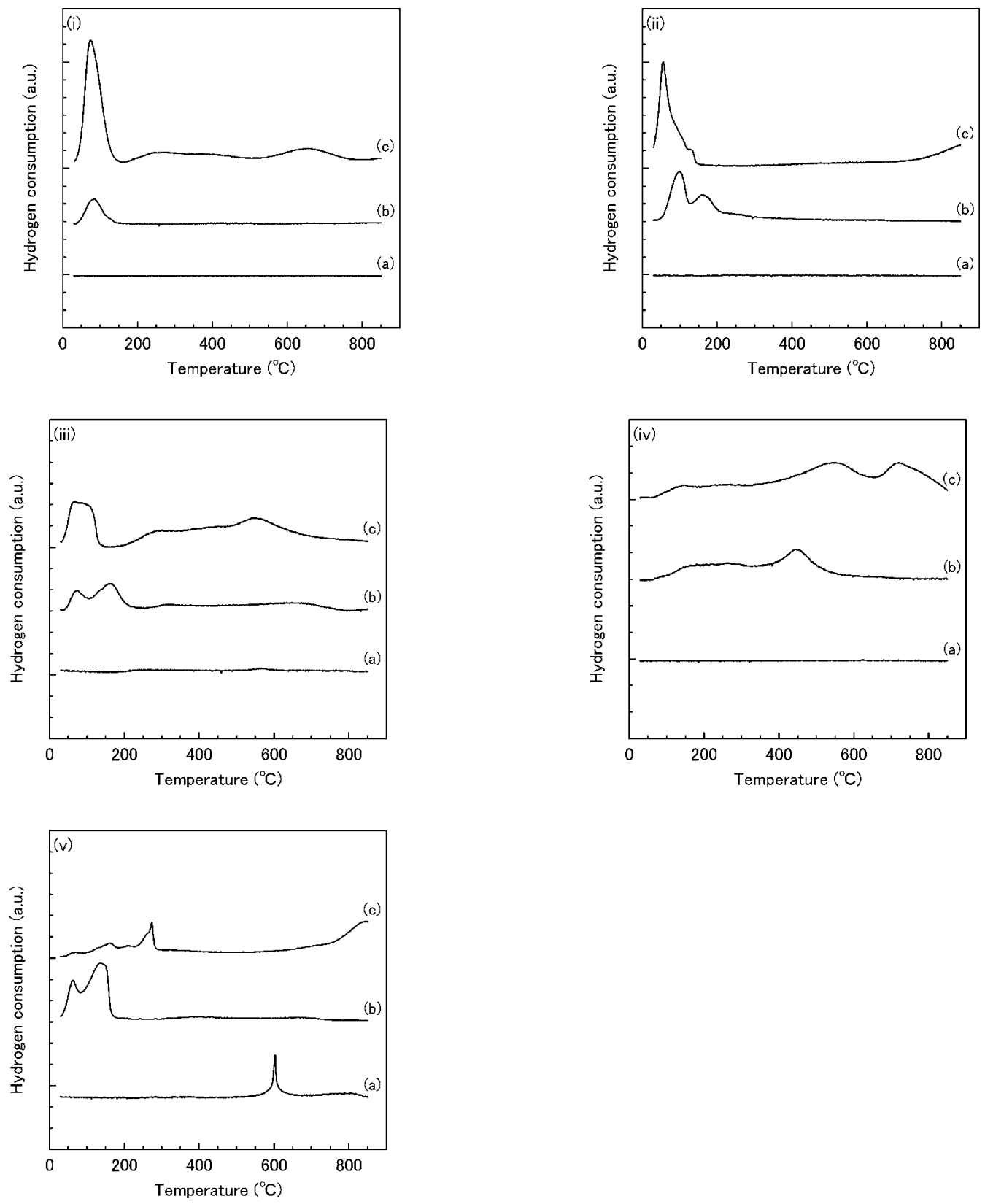

Support: (i) $\mathrm{SiO}_{2}$, (ii) $\mathrm{Al}_{2} \mathrm{O}_{3}$, (iii) $\mathrm{TiO}_{2}$, (iv) $\mathrm{MgO}$, (v) $\mathrm{ZrO}_{2}$.

(a) Support, (b) Rh catalyst, (c) Rh-P catalysts.

Fig. 3 TPR Spectra of Rh and Rh-P Catalysts

dispersed $\mathrm{MgRh}_{2} \mathrm{O}_{4}$ is present in the $\mathrm{Rh}-\mathrm{P} / \mathrm{MgO}$ catalyst.

\section{1.3. XRD Patterns of Reduced Rh/MO $x$ and Rh-P/MO ${ }_{x}$ Catalysts}

The XRD patterns of reduced catalysts were examined to evaluate the formed Rh species. The XRD patterns of reduced $\mathrm{Rh}$ and $\mathrm{Rh}-\mathrm{P}$ catalysts are shown in Figs. 1 and 2. In Rh catalysts (Fig. 1), except Rh/ $\mathrm{Al}_{2} \mathrm{O}_{3}$, the peaks of $\mathrm{Rh}\left(2 \theta=41.1,47.9,70.0\right.$ and $\left.84.5^{\circ}\right)$ were observed and the intensity of peaks increased with higher reduction temperature. On the other hand, the peaks of $\mathrm{Rh}_{2} \mathrm{P}\left(2 \theta=41.1,47.9,70.0\right.$ and $\left.84.5^{\circ}\right)$ appeared in the XRD patterns of reduced $\mathrm{Rh}-\mathrm{P} / \mathrm{MO}_{x}$ catalysts, as shown in Fig. 2. However, the reduction temperature required for the appearance of $\mathrm{Rh}_{2} \mathrm{P}$ peaks was remarkably changed by the type of support. This tendency was the same as that found by TPR spectra, as shown in Fig. 3. The relationships between reduction temperature and $\mathrm{Rh}$ species detected by XRD of $\mathrm{Rh}-\mathrm{P}$ catalysts are listed in Table $1 . \mathrm{Rh}_{2} \mathrm{P}$ was formed in $\mathrm{Rh}-\mathrm{P} / \mathrm{SiO}_{2}$ and $\mathrm{Rh}-\mathrm{P} / \mathrm{TiO}_{2}$ catalysts reduced at $450{ }^{\circ} \mathrm{C}$. Metallic $\mathrm{Rh}$ was only observed in $\mathrm{Rh}-\mathrm{P} / \mathrm{Al}_{2} \mathrm{O}_{3}$ and $\mathrm{Rh}^{-}$ 
Table 1 Observed Rh Species by XRD in Rh and Rh-P Catalysts Reduced at Various Temperatures

\begin{tabular}{cccccc}
\hline \multirow{2}{*}{ Support } & \multicolumn{5}{c}{$\mathrm{Rh}$ species } \\
\cline { 2 - 6 } & $450{ }^{\circ} \mathrm{C}$ & $550{ }^{\circ} \mathrm{C}$ & $650{ }^{\circ} \mathrm{C}$ & $750{ }^{\circ} \mathrm{C}$ & $850{ }^{\circ} \mathrm{C}$ \\
\hline $\mathrm{SiO}_{2}$ & $\mathrm{Rh}, \mathrm{Rh}_{2} \mathrm{P}$ & $\mathrm{Rh}_{2} \mathrm{P}$ & $\mathrm{Rh}_{2} \mathrm{P}$ & - & - \\
$\mathrm{Al}_{2} \mathrm{O}_{3}$ & $\mathrm{Rh}$ & $\mathrm{Rh}$ & $\mathrm{Rh}$ & $\mathrm{Rh}, \mathrm{Rh}_{2} \mathrm{P}$ & $\mathrm{Rh}_{2} \mathrm{P}$ \\
$\mathrm{TiO}_{2}$ & $\mathrm{Rh}_{2} \mathrm{P}$ & $\mathrm{Rh}_{2} \mathrm{P}$ & $\mathrm{Rh}_{2} \mathrm{P}$ & - & - \\
$\mathrm{MgO}^{-}$ & $-\mathrm{Rh}_{2} \mathrm{P}$ & $\mathrm{Rh}_{2} \mathrm{P}$ & - & - \\
$\mathrm{ZrO}_{2}$ & $\mathrm{Rh}$ & $\mathrm{Rh}_{2} \mathrm{Rh}_{2} \mathrm{P}$ & $\mathrm{Rh}_{2} \mathrm{Rh}_{2} \mathrm{P}$ & $\mathrm{Rh}_{2} \mathrm{P}$ & - \\
\hline
\end{tabular}

a) No peaks of $\mathrm{Rh}$ species were observed.

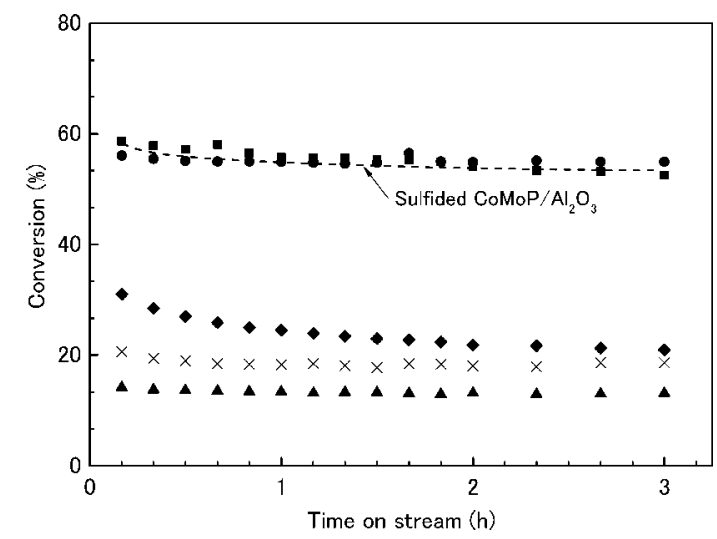

$\mathrm{SiO}_{2}, \boldsymbol{\Delta} \mathrm{Al}_{2} \mathrm{O}_{3}, \boldsymbol{\mathrm { TiO } _ { 2 }}, \boldsymbol{\mathrm { MgO }}, \times \mathrm{ZrO}_{2}$.

Fig. 4 HDS Conversion of Thiophene over Rh-P/MO ${ }_{x}$ Catalysts Reduced at $550{ }^{\circ} \mathrm{C}$

$\mathrm{P} / \mathrm{ZrO}_{2}$ catalysts reduced at the same temperature. On the other hand, no peaks of Rh species were observed in the $\mathrm{Rh}-\mathrm{P} / \mathrm{MgO}$ catalyst reduced at $450{ }^{\circ} \mathrm{C}$. Since the reduction peak attributed to $\mathrm{MgRh}_{2} \mathrm{O}_{4}$ was observed at $550{ }^{\circ} \mathrm{C}$ in the TPR spectrum of $\mathrm{Rh}-\mathrm{P} / \mathrm{MgO}$ (Fig. 3 (iv), (c)), formation of $\mathrm{Rh}_{2} \mathrm{P}$ did not occur in the $\mathrm{Rh}-\mathrm{P} /$ $\mathrm{MgO}$ reduced at $450{ }^{\circ} \mathrm{C} . \quad \mathrm{Rh}_{2} \mathrm{P}$ was formed in all $\mathrm{Rh}-\mathrm{P}$ catalysts with higher reduction temperature. However, metallic $\mathrm{Rh}$ species were observed in $\mathrm{Rh}-\mathrm{P} / \mathrm{Al}_{2} \mathrm{O}_{3}$ and $\mathrm{Rh}-\mathrm{P} / \mathrm{ZrO}_{2}$ catalysts reduced at $750{ }^{\circ} \mathrm{C}$ and $650{ }^{\circ} \mathrm{C}$, respectively. This observation indicates that formation of $\mathrm{Rh}_{2} \mathrm{P}$ is more difficult on $\mathrm{Al}_{2} \mathrm{O}_{3}$ and $\mathrm{ZrO}_{2}$ than on other supports. The trend of these results agrees with that of TPR spectra, as shown in Fig. 3.

\section{2. HDS Activities of Rh/MO ${ }_{x}$ and $\mathrm{Rh}-\mathrm{P} / \mathrm{MO}_{x}$ Catalysts}

Figure 4 shows the HDS conversion of thiophene over $\mathrm{Rh}-\mathrm{P} / \mathrm{MO}_{x}$ catalysts reduced at $550{ }^{\circ} \mathrm{C}$. The $\mathrm{Rh}^{-}$ $\mathrm{P}$ catalysts showed stable activities with time-on-stream. However, the HDS activity of $\mathrm{Rh}-\mathrm{P} / \mathrm{MgO}$ catalyst remarkably decreased. It is well known that sulfur tolerance is increased by the acidity of the support ${ }^{12), 13), 32) ~ 34)}$. In contrast, $\mathrm{MgO}$ has basic properties indicating that the sulfur tolerance of $\mathrm{Rh}-\mathrm{P} / \mathrm{MgO}$ catalyst would be lower than that of other $\mathrm{Rh}-\mathrm{P} / \mathrm{MO}_{x}$ catalysts, thus accounting for the remarkable decrease of HDS activity
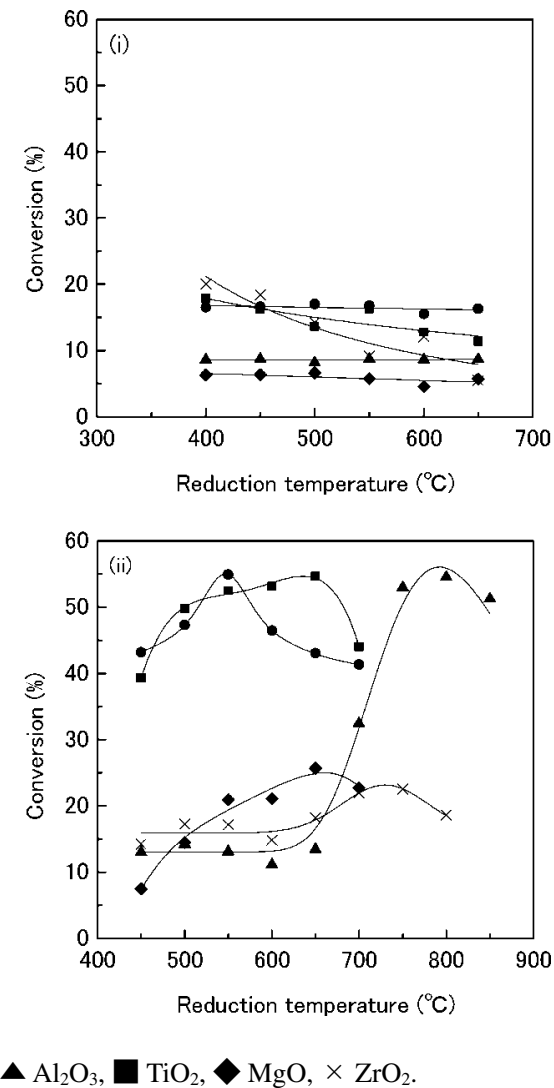

Fig. 5 Effect of Reduction Temperature on HDS Activities of (i) Rh and (ii) $\mathrm{Rh}-\mathrm{P}$ Catalysts

with time-on-stream observed with the $\mathrm{Rh}-\mathrm{P} / \mathrm{MgO}$ catalyst.

We previously reported that the HDS activity of $\mathrm{Rh}^{-}$ $\mathrm{P} / \mathrm{SiO}_{2}$ catalyst was remarkably changed by the reduction temperature. Therefore, the effect of reduction temperature was examined on the HDS activities of Rh and $\mathrm{Rh}-\mathrm{P}$ catalysts after $3 \mathrm{~h}$ reaction. Reduction temperature hardly affected the HDS activities of $\mathrm{Rh}$ catalyst with $\mathrm{SiO}_{2}, \mathrm{Al}_{2} \mathrm{O}_{3}$ and $\mathrm{MgO}$ supports, as shown in Fig. 5 (i). However, increasing reduction temperature reduced the HDS activities of $\mathrm{TiO}_{2}$ and $\mathrm{ZrO}_{2}$-supported $\mathrm{Rh}$ catalysts. In contrast, reduction temperature strongly affected the HDS activities of all $\mathrm{Rh}-\mathrm{P} / \mathrm{MO}_{x}$ catalysts, as shown in Fig. 5 (ii). The HDS activities of $\mathrm{Rh}-\mathrm{P}$ catalysts changed with increasing reduction temperature. The highest activity appeared at lower reduction temperature $\left(550{ }^{\circ} \mathrm{C}\right)$ using $\mathrm{SiO}_{2}$ support, whereas the highest HDS activities occurred on other supports reduced at higher temperature (above $650{ }^{\circ} \mathrm{C}$ ). In particular, the reduction temperature for optimal HDS activity of $\mathrm{Rh}-\mathrm{P} / \mathrm{Al}_{2} \mathrm{O}_{3}$ catalyst was $800{ }^{\circ} \mathrm{C}$. The optimal reduction temperature for the highest activity remarkably changed with the type of $\mathrm{MO}_{x}$ support. The explanation for these findings is that the formation temperature of $\mathrm{Rh}_{2} \mathrm{P}$ significantly depends on the type of $\mathrm{MO}_{x}$ support, as shown in Fig. 2 and Table 1. 
Figure 6 shows the HDS activities of $\mathrm{Rh}$ and $\mathrm{Rh}-\mathrm{P}$ catalysts reduced at the optimal temperatures. $\mathrm{Rh}-\mathrm{P} / \mathrm{MO}_{x}$ catalyst showed higher activity than $\mathrm{Rh} / \mathrm{MO}_{x}$ catalyst, indicating that formation of $\mathrm{Rh}_{2} \mathrm{P}$ by $\mathrm{P}$ addition and reduction with hydrogen leads to enhanced activity. The order of HDS activities was as follows; $\mathrm{SiO}_{2} \sim \mathrm{TiO}_{2} \sim$ $\mathrm{Al}_{2} \mathrm{O}_{3}>\mathrm{MgO}>\mathrm{ZrO}_{2}$

Table 2 shows the product distribution of thiophene HDS for various $\mathrm{Rh} / \mathrm{MO}_{x}$ and $\mathrm{Rh}-\mathrm{P} / \mathrm{MO}_{x}$ catalysts reduced at the optimal temperature. Reduced and sulfided $\mathrm{Rh} / \mathrm{SiO}_{2}$ catalyst, as well as $\mathrm{NiMo} / \mathrm{Al}_{2} \mathrm{O}_{3}$ catalyst, favored the direct desulfurization route with high biphenyl (BP) selectivity for the HDS of dibenzothiophene ${ }^{30)}$. On the other hand, $\mathrm{Rh}_{2} \mathrm{P} / \mathrm{SiO}_{2}$ catalyst favored the hydrodesulfurization route with low BP selectivity ${ }^{30)}$. In our study, the selectivities of butanes and tetrahydrothiophene (THT) for Rh catalysts were increased by $\mathrm{P}$ addition, indicating that $\mathrm{Rh}-\mathrm{P} / \mathrm{MO}_{x}$ catalysts would favor the hydrogenation route compared

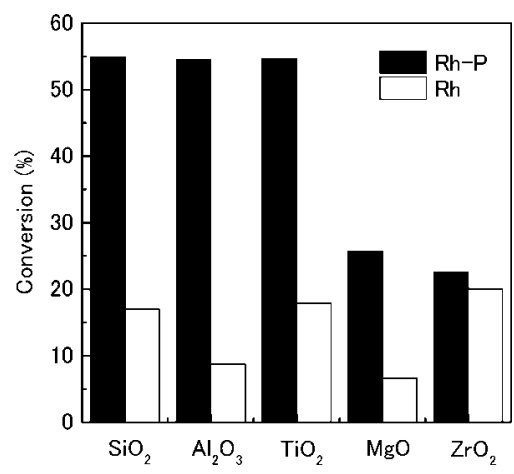

Rh catalyst: $400{ }^{\circ} \mathrm{C}$; $\mathrm{TiO}_{2}, \mathrm{ZrO}_{2}, 450{ }^{\circ} \mathrm{C} ; \mathrm{Al}_{2} \mathrm{O}_{3}, 500{ }^{\circ} \mathrm{C}$; $\mathrm{SiO}_{2}, \mathrm{MgO}$. Rh-P catalyst: $550{ }^{\circ} \mathrm{C} ; \mathrm{SiO}_{2}, 650{ }^{\circ} \mathrm{C}$; $\mathrm{TiO}_{2}, \mathrm{MgO}, 700{ }^{\circ} \mathrm{C} ; \mathrm{ZrO}_{2}$, $800{ }^{\circ} \mathrm{C} ; \mathrm{Al}_{2} \mathrm{O}_{3}$.

Fig. 6 HDS Activities of Rh and Rh-P Catalysts Reduced at Optimal Temperature with $\mathrm{Rh} / \mathrm{MO}_{x}$ catalysts. The $\mathrm{SiO}_{2}, \mathrm{Al}_{2} \mathrm{O}_{3}$ and $\mathrm{TiO}_{2}$ supported $\mathrm{Rh}-\mathrm{P}$ catalysts showed the same conversion and selectivities of products. These results show that the reaction mechanism for HDS of thiophene is little changed by the type of support. The $\mathrm{Rh}-\mathrm{P} / \mathrm{MgO}$ and $\mathrm{Rh}-\mathrm{P} / \mathrm{ZrO}_{2}$ catalysts showed higher THT selectivity than other Rh-P catalysts, which can be explained by the low conversion of thiophene. However, since $\mathrm{Rh}^{-}$ $\mathrm{P} / \mathrm{ZrO}_{2}$ catalyst showed slightly lower HDS activity than $\mathrm{Rh}-\mathrm{P} / \mathrm{MgO}$ catalyst, the remarkably high THT selectivity of $\mathrm{Rh}-\mathrm{P} / \mathrm{ZrO}_{2}$ cannot be explained by such low conversion. This result will be discussed in section 3. 3. 2.

\section{3. Characterization of $\mathrm{Rh}$ and $\mathrm{Rh}-\mathrm{P}$ Catalysts 3. 3. 1. BET Surface Area of Calcined Rh and Rh- P Catalysts}

Table 3 shows the BET surface area of $\mathrm{MO}_{x}$ supports, and calcined $\mathrm{Rh} / \mathrm{MO}_{x}$ and $\mathrm{Rh}-\mathrm{P} / \mathrm{MO}_{x}$ catalysts. The order of surface area of $\mathrm{MO}_{x}$ was as follows; $\mathrm{SiO}_{2}$ $>\mathrm{Al}_{2} \mathrm{O}_{3}>\mathrm{TiO}_{2}>\mathrm{MgO}>\mathrm{ZrO}_{2}$. The surface area of $\mathrm{SiO}_{2}, \mathrm{Al}_{2} \mathrm{O}_{3}$ and $\mathrm{TiO}_{2}$ hardly decreased after $\mathrm{Rh}$ loading, showing that Rh species were highly dispersed on these $\mathrm{MO}_{x}$ supports. On the other hand, the surface area of $\mathrm{Rh} / \mathrm{MgO}$ catalyst was increased by $\mathrm{Rh}$ loading. The XRD patterns showed the intensity of the main peak attributed to $\mathrm{MgO}\left(2 \theta=42.9^{\circ}, 10174 \mathrm{cps}\right)$ was remarkably smaller for calcined $\mathrm{Rh} / \mathrm{MgO}$ than for $\mathrm{MgO}$ support (Rh unloaded, $25385 \mathrm{cps}$ ). Furthermore, the crystalline size of $\mathrm{MgO}$ (37.3 nm) calculated by Scherrer's equation decreased after $\mathrm{Rh}$ loading $(21.0 \mathrm{~nm})$, indicating that the surface of $\mathrm{MgO}$ had partially dissolved in the acidic $\mathrm{RhCl}_{3} \cdot 3 \mathrm{H}_{2} \mathrm{O}$ aqueous solution. Therefore, the increase of surface area by Rh loading can be explained by the reaction of leached $\mathrm{Mg}$ species with $\mathrm{Rh}$ species to form $\mathrm{MgRh}_{2} \mathrm{O}_{4}$ as observed in Fig. 3 (iv), (b). Increased surface area was also observed for $\mathrm{Rh} /$ $\mathrm{ZrO}_{2}$ catalyst. The $\mathrm{HCl}$ impregnated $\mathrm{ZrO}_{2}$, which contained the same amount of $\mathrm{Cl}$ as $\mathrm{RhCl}_{3} \cdot 3 \mathrm{H}_{2} \mathrm{O}$ aqueous

Table 2 Distribution of Reaction Products in the HDS of Thiophene over Rh and Rh-P Catalysts Reduced at Optimal Temperature

\begin{tabular}{cccccccc}
\hline \multirow{2}{*}{ Catalyst } & Reduction temperature $\left[{ }^{\circ} \mathrm{C}\right]$ & Conversion [\%] & \multicolumn{5}{c}{ Composition of HDS products [\%] } \\
\cline { 5 - 8 } & & & $\mathrm{C}_{1}-\mathrm{C}_{3}{ }^{\text {a) }}$ & Butanes & Butenes & 1,3-Butadiene & $\mathrm{THT}^{\mathrm{b})}$ \\
\hline $\mathrm{Rh}$ & & & & & & & \\
$\mathrm{SiO}_{2}$ & 500 & 17.01 & 0.25 & 10.36 & 85.93 & 0.00 & 3.45 \\
$\mathrm{Al}_{2} \mathrm{O}_{3}$ & 450 & 17.75 & 1.86 & 14.71 & 82.17 & 0.00 & 1.26 \\
$\mathrm{TiO}_{2}$ & 400 & 6.61 & 0.80 & 13.64 & 82.60 & 0.00 & 2.96 \\
$\mathrm{MgO}$ & 500 & 20.03 & 0.27 & 10.53 & 85.52 & 0.00 & 3.68 \\
$\mathrm{ZrO}$ & 400 & & & 12.29 & 82.28 & 0.10 & 5.24 \\
$\mathrm{Rh}_{2}$ & & 54.95 & 0.11 & 20.82 & 75.54 & 0.00 & 3.53 \\
$\mathrm{SiO}_{2}$ & 550 & 54.55 & 0.16 & 20.86 & 75.15 & 0.01 & 3.83 \\
$\mathrm{Al}_{2} \mathrm{O}_{3}$ & 800 & 54.64 & 0.06 & 21.46 & 74.77 & 0.00 & 3.70 \\
$\mathrm{TiO}_{2}$ & 650 & 25.67 & 0.00 & 11.45 & 82.87 & 0.00 & 5.66 \\
$\mathrm{MgO}$ & 650 & 22.53 & 0.15 & 7.74 & 78.46 & 0.00 & 13.64 \\
$\mathrm{ZrO}_{2}$ & 750 & & & & & & \\
\hline
\end{tabular}

a) $\mathrm{C}_{1}-\mathrm{C}_{3}$ hydrocarbons.

b) Tetrahydrothiophene. 
Table 3 BET Surface Area of $\mathrm{MO}_{x}$ Supports and Rh and Rh-P Catalysts Measured by $\mathrm{N}_{2}$ Adsorption at $-196{ }^{\circ} \mathrm{C}$

\begin{tabular}{cccc}
\hline \multirow{2}{*}{ Support } & \multicolumn{3}{c}{ Surface area $\left[\mathrm{m}^{2} \cdot \mathrm{g}^{-1}\right]$} \\
\cline { 2 - 4 } & Support & Supported Rh catalyst & Supported Rh-P catalyst \\
\hline $\mathrm{SiO}_{2}$ & 295 & 289 & 249 \\
$\mathrm{Al}_{2} \mathrm{O}_{3}$ & 101 & 101 & 88 \\
$\mathrm{TiO}_{2}$ & 56 & 54 & 52 \\
$\mathrm{MgO}_{\mathrm{ZrO}}$ & 26 & 64 & 71 \\
\hline
\end{tabular}

Table 4 Crystallite Size of Rh Calculated from XRD Patterns in Rh Catalysts Reduced at Various Temperatures

\begin{tabular}{crcc}
\hline & \multicolumn{3}{c}{ Crystalline size $[\mathrm{nm}]$} \\
\cline { 2 - 4 } Support & $450{ }^{\circ} \mathrm{C}$ & $550{ }^{\circ} \mathrm{C}$ & $650{ }^{\circ} \mathrm{C}$ \\
\hline $\mathrm{SiO}_{2}$ & 2.4 & 2.4 & 2.9 \\
$\mathrm{Al}_{2} \mathrm{O}_{3}$ & 0.8 & 1.1 & 1.0 \\
$\mathrm{TiO}_{2}$ & $-{ }^{\mathrm{a})}$ & 2.3 & 4.1 \\
$\mathrm{MgO}$ & 2.0 & 2.5 & 3.6 \\
$\mathrm{ZrO}_{2}$ & 25.7 & 28.3 & 35.4 \\
\hline
\end{tabular}

a) No peaks of $\mathrm{Rh}$ were observed.

solution and was prepared by the same procedure for preparing supported Rh catalyst, showed the same surface area as the original $\mathrm{ZrO}_{2}\left(5 \mathrm{~m}^{2} \cdot \mathrm{g}^{-1}\right)$, indicating that treatment with acidic solution did not enhance the surface area of $\mathrm{ZrO}_{2}$. The XRD pattern of calcined $\mathrm{Rh} /$ $\mathrm{ZrO}_{2}$ catalyst contained no peaks of $\mathrm{Rh}_{2} \mathrm{O}_{3}$ and $\mathrm{Rh}$ as shown in Fig. 1 (v), (b). Thus, calcined $\mathrm{Rh} / \mathrm{ZrO}_{2}$ catalyst has high $\mathrm{Rh}_{2} \mathrm{O}_{3}$ dispersion. Assuming that the particle shape of $\mathrm{Rh}_{2} \mathrm{O}_{3}$ is spherical and the particle size is $5 \mathrm{~nm}$, the surface area of $\mathrm{Rh}_{2} \mathrm{O}_{3}$ particles calculated from $S=6 / \rho d$ ( $S$ : surface area, $\rho$ : density of $\mathrm{Rh}_{2} \mathrm{O}_{3}, d$ : diameter) is approximately $145 \mathrm{~m}^{2} \cdot \mathrm{g}^{-1}$. Even if $\mathrm{Rh}$ loading is very low (5 mass\%) compared with the $\mathrm{ZrO}_{2}$ support, the surface area of $\mathrm{Rh}_{2} \mathrm{O}_{3}$ was remarkably higher than that of the $\mathrm{ZrO}_{2}$ support. Therefore, high dispersion of Rh species leads to increased surface area. Furthermore, $\mathrm{Rh}-\mathrm{P} / \mathrm{MO}_{x}$ catalysts, except for $\mathrm{Rh}-\mathrm{P} /$ $\mathrm{MgO}$, had lower surface area than $\mathrm{MO}_{x}$ supports and $\mathrm{Rh} / \mathrm{MO}_{x}$ catalysts, indicating that phosphate addition causes aggregation of Rh species. The high surface area of $\mathrm{Rh}-\mathrm{P}$ catalyst using $\mathrm{MgO}$ support was attributed to the formation of $\mathrm{MgRh}_{2} \mathrm{O}_{4}$ as shown in Fig. 3 (iv), (c).

\section{3. 2. Crystalline Sizes of $R h$ and $R h_{2} P$ Calculated from XRD}

Crystalline sizes of $\mathrm{Rh}$ and $\mathrm{Rh}_{2} \mathrm{P}$ were calculated from XRD patterns using Scherrer's equation to evaluate the effect of reduction temperature on particle size. Table 4 shows the crystalline size of $\mathrm{Rh}$ in $\mathrm{Rh} / \mathrm{MO}_{x}$ catalysts reduced at various temperatures. The smallest crystalline sizes $(<5 \mathrm{~nm})$ for $\mathrm{Rh}$ were observed in $\mathrm{Rh} / \mathrm{MO}_{x}$ catalysts, except for $\mathrm{Rh} / \mathrm{ZrO}_{2}$ catalyst, reduced at various temperatures, indicating that the Rh particles are highly dispersed on $\mathrm{MO}_{x}$ supports. However, the crystalline size of $\mathrm{Rh}$ on $\mathrm{ZrO}_{2}$ was remarkable larger compared to that on other $\mathrm{MO}_{x}$ supports. On the other hand, $\mathrm{Rh}$ species were highly dispersed on $\mathrm{ZrO}_{2}$ support after calcination (Fig. 1 (v), (b) and Table 3). These results indicate that the particle size of Rh grows considerably after reduction.

The crystalline sizes of $\mathrm{Rh}$ and $\mathrm{Rh}_{2} \mathrm{P}$ in $\mathrm{Rh}-\mathrm{P} / \mathrm{MO}_{x}$ catalysts are listed in Table 5. The crystalline sizes of $\mathrm{Rh}$ in $\mathrm{Rh}-\mathrm{P}$ catalysts were larger than in Rh catalysts, in accordance with the trend in BET surface area, as shown in Table 3. The crystalline size of $\mathrm{Rh}_{2} \mathrm{P}$ was smaller than that of $\mathrm{Rh}$ in all $\mathrm{Rh}-\mathrm{P}$ catalysts, showing that small $\mathrm{Rh}$ particles may preferentially react with reduced $\mathrm{P}$ to form $\mathrm{Rh}_{2} \mathrm{P}$. The $\mathrm{Rh}-\mathrm{P} / \mathrm{ZrO}_{2}$ catalyst had remarkable larger crystalline size of $\mathrm{Rh}_{2} \mathrm{P}$ compared with other $\mathrm{Rh}-\mathrm{P} / \mathrm{MO}_{x}$ catalysts. Small noble metal particles are reported to show greater sulfur tolerance ${ }^{37}$. Consequently, the $\mathrm{Rh}-\mathrm{P} / \mathrm{ZrO}_{2}$ catalyst had low sulfur tolerance. $\mathrm{H}_{2} \mathrm{~S}$ formed by the HDS reaction of thiophene would poison the active sites for $\mathrm{C}-\mathrm{S}$ bond cleavage on low sulfur tolerant $\mathrm{Rh}_{2} \mathrm{P}$ catalyst. Therefore, the remarkably high THT selectivity of $\mathrm{Rh}-\mathrm{P} / \mathrm{ZrO}_{2}$ catalyst (Table 2) can be explained by the low conversion and low sulfur tolerance due to the large $\mathrm{Rh}_{2} \mathrm{P}$ particles.

\section{3. 3. CO Adsorption on $\mathrm{Rh} / \mathrm{MO}_{x}$ and $\mathrm{Rh}-\mathrm{P} / \mathrm{MO}_{\boldsymbol{x}}$ Catalysts}

The $\mathrm{CO}$ uptakes of $\mathrm{Rh}$ and $\mathrm{Rh}-\mathrm{P}$ catalysts were examined to evaluate the HDS activities by turnover frequency (TOF). Figure 7 shows the CO uptake of $\mathrm{Rh}$ and $\mathrm{Rh}-\mathrm{P}$ catalysts as a function of reduction temperature. $\mathrm{Rh} / \mathrm{Al}_{2} \mathrm{O}_{3}$ catalyst showed remarkably higher $\mathrm{CO}$ uptake compared to other $\mathrm{Rh} / \mathrm{MO}_{x}$ catalysts. Assuming that $\mathrm{CO}$ molecules are linearly adsorbed onto $\mathrm{Rh}$ atom, $\mathrm{Rh}$ dispersion in $\mathrm{Rh} / \mathrm{Al}_{2} \mathrm{O}_{3}$ catalyst reduced at $400{ }^{\circ} \mathrm{C}$ was about 1.3. After $\mathrm{CO}$ was adsorbed on $\mathrm{Rh} /$ $\mathrm{Al}_{2} \mathrm{O}_{3}$ catalyst with high dispersion, the $\mathrm{Rh}(\mathrm{CO})_{2}$ species was identified by infrared spectroscopy ${ }^{38)}$. Thus, the remarkable $\mathrm{CO}$ uptake of $\mathrm{Rh} / \mathrm{Al}_{2} \mathrm{O}_{3}$ could be explained by the formation of $\mathrm{Rh}(\mathrm{CO})_{2}$ species. On the other hand, remarkable decrease of $\mathrm{CO}$ uptake was observed in $\mathrm{Rh} / \mathrm{TiO}_{2}$ catalyst with increasing reduction temperature. $\mathrm{TiO}_{2}$ is a well-known reducible support and supported metals on reducible supports are covered by suboxide species such as $\mathrm{TiO}_{x}(x<2)$, a phenomenon 
Table 5 Crystallite Size of $\mathrm{Rh}$ and $\mathrm{Rh}_{2} \mathrm{P}$ Calculated from XRD Patterns in $\mathrm{Rh}-\mathrm{P}$ Catalysts Reduced at Various Temperatures

\begin{tabular}{|c|c|c|c|c|c|}
\hline \multirow{2}{*}{ Support } & \multicolumn{5}{|c|}{ Crystalline size [nm] } \\
\hline & $450{ }^{\circ} \mathrm{C}$ & $550{ }^{\circ} \mathrm{C}$ & $650{ }^{\circ} \mathrm{C}$ & $750{ }^{\circ} \mathrm{C}$ & $850{ }^{\circ} \mathrm{C}$ \\
\hline \multicolumn{6}{|l|}{$\mathrm{Rh}$} \\
\hline $\mathrm{SiO}_{2}$ & 6.2 & - $^{\text {a) }}$ & - $^{\text {a) }}$ & - & - \\
\hline $\mathrm{Al}_{2} \mathrm{O}_{3}$ & 4.8 & 5.1 & 5.6 & 9.6 & - $^{\text {a) }}$ \\
\hline $\mathrm{TiO}_{2}$ & - $^{\text {a) }}$ & - $^{\text {a) }}$ & - $^{\text {a) }}$ & - & - \\
\hline $\mathrm{MgO}$ & - $^{\text {a) }}$ & - $^{\text {a) }}$ & - $^{\text {a) }}$ & - & - \\
\hline $\mathrm{ZrO}_{2}$ & 29.3 & 32.6 & 34.0 & $-^{\text {a) }}$ & - \\
\hline \multicolumn{6}{|l|}{$\mathrm{Rh}_{2} \mathrm{P}$} \\
\hline $\mathrm{SiO}_{2}$ & 4.0 & 5.6 & 7.0 & - & - \\
\hline $\mathrm{Al}_{2} \mathrm{O}_{3}$ & — $^{\mathrm{b})}$ & — $^{\mathrm{b})}$ & $-^{\mathrm{b})}$ & 5.3 & 8.5 \\
\hline $\mathrm{TiO}_{2}$ & 9.1 & 10.7 & 11.7 & - & - \\
\hline $\mathrm{MgO}$ & —) $^{\mathrm{b}}$ & 4.7 & 11.3 & - & - \\
\hline $\mathrm{ZrO}_{2}$ & — $^{\mathrm{b})}$ & 6.3 & 18.4 & 33.3 & - \\
\hline
\end{tabular}

a) No peaks of Rh were observed.

b) No peaks of $\mathrm{Rh}_{2} \mathrm{P}$ were observed.
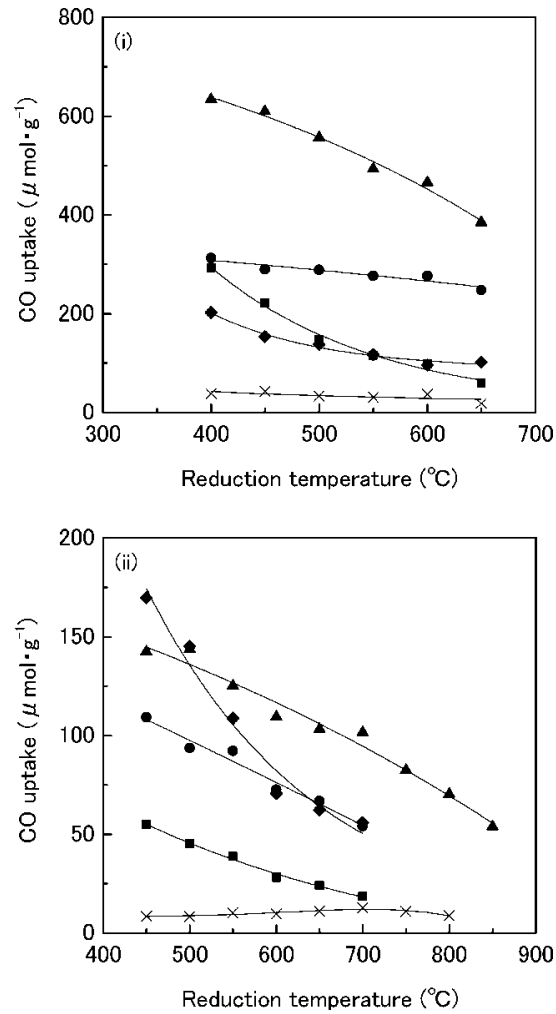

$\mathrm{SiO}_{2}, \boldsymbol{\Delta} \mathrm{Al}_{2} \mathrm{O}_{3}$

$\mathrm{TiO}_{2}$

$\mathrm{MgO}, \times \mathrm{ZrO}_{2}$

Fig. 7 Relationship between Reduction Temperature and CO Uptake of (i) Rh and (ii) Rh-P Catalysts

called strong metal support interaction (SMSI) ${ }^{39), 40)}$. The peak of $\mathrm{TiO}_{2}$ reduction appeared in the TPR spectrum of $\mathrm{Rh} / \mathrm{TiO}_{2}$, as shown in Fig. 3 (iii), (b). Thus, the SMSI effect would result in remarkable decrease of $\mathrm{CO}$ uptake of $\mathrm{Rh} / \mathrm{TiO}_{2}$ with increasing reduction temperature. The CO uptake of $\mathrm{Rh}-\mathrm{P}$ catalysts decreased compared with $\mathrm{Rh}$ catalysts, indicating aggregation of
Rh species and $\mathrm{Rh}_{2} \mathrm{P}$ species formation on $\mathrm{MO}_{x}$ supports. Furthermore, $\mathrm{CO}$ uptake of $\mathrm{Rh}-\mathrm{P} / \mathrm{TiO}_{2}$ catalyst decreased with increasing reduction temperature, but was similar to that of $\mathrm{Al}_{2} \mathrm{O}_{3}$ and $\mathrm{SiO}_{2}$-supported $\mathrm{Rh}-\mathrm{P}$ catalysts. Phosphorus addition presumably inhibited covering of the $\mathrm{Rh}_{2} \mathrm{P}$ surface by $\mathrm{TiO}_{x}$ species.

Figure 8 shows the TOF of Rh and Rh-P catalysts for HDS of thiophene. The TOF was calculated using the $\mathrm{CO}$ uptake (assumed $\mathrm{CO} / \mathrm{Rh}=1$ ). The TOF of Rh catalysts, except $\mathrm{Rh} / \mathrm{ZrO}_{2}$, increased with higher reduction temperature. The TOF of $\mathrm{Pt} / \mathrm{Al}_{2} \mathrm{O}_{3}$ catalyst for thiophene HDS decreases with lower dispersion of $\mathrm{Pt}^{41)}$. Therefore, increased TOF of Rh catalysts would be caused by enlargement of the Rh crystalline size, as shown in Table 4. However, the TOF of $\mathrm{Rh} / \mathrm{ZrO}_{2}$ catalyst decreased with higher reduction temperature. $\mathrm{ZrO}_{2}$ is well known to have acidic and basic properties. The acidity and basicity changed with calcination temperature. High calcination temperature leads to increased number of acidic sites without change in acid strength $^{42), 43)}$. On the other hand, elevation of calcination temperature increases the number of basic sites and enhances the base strength of these sites ${ }^{42), 43)}$. Therefore, high reduction temperature would lead to changes in the acidity and basicity of the $\mathrm{ZrO}_{2}$ support. The acidity of the support enhanced sulfur tolerance of the supported noble metal catalysts ${ }^{12), 13), 32) ~ 34) . ~ T h e ~}$ opposite trend in TOF is explained by the formation of strong basic sites on the $\mathrm{ZrO}_{2}$ support which weakens the sulfur tolerance of the Rh particles.

On the other hand, the TOF of Rh-P catalysts significantly increased with higher reduction temperature. $\mathrm{CO}$ adsorbed on the two-fold Ni bridge site and formation of $\mathrm{Ni}(\mathrm{CO})_{4}$, which are observed on supported $\mathrm{Ni}$ catalyst, are suppressed for the supported nickel phosphide $\left(\mathrm{Ni}_{2} \mathrm{P}\right.$ and $\left.\mathrm{Ni}_{12} \mathrm{P}_{5}\right)$ catalysts, and linearly bounded $\mathrm{CO}$ is observed by FT-IR ${ }^{22)}$. Therefore, $\mathrm{CO}$ will lin- 

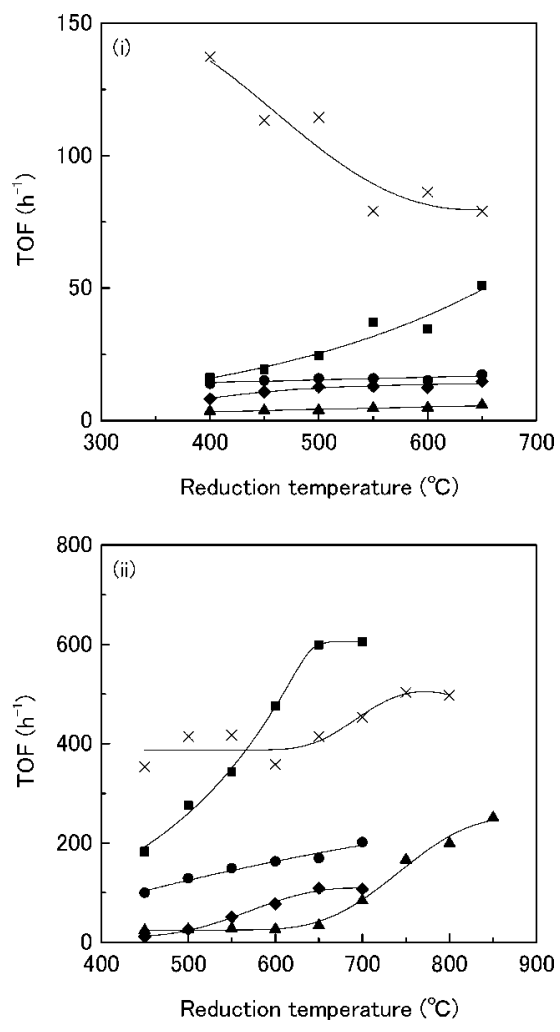

$\mathrm{SiO}_{2}, \boldsymbol{\Delta} \mathrm{Al}_{2} \mathrm{O}_{3}, \boldsymbol{\mathrm { TiO } _ { 2 }}, \boldsymbol{\mathrm { MgO }}, \times \mathrm{ZrO}_{2}$

Fig. 8 Relationship between Reduction Temperature and TOF of (i) $\mathrm{Rh}$ and (ii) $\mathrm{Rh}-\mathrm{P}$ Catalysts

early adsorb on $\mathrm{Rh}_{2} \mathrm{P}$ catalyst as well as $\mathrm{Ni}_{2} \mathrm{P}$ catalyst. Furthermore, remarkable increase in TOF of $\mathrm{Al}_{2} \mathrm{O}_{3}$ and $\mathrm{ZrO}_{2}$-supported $\mathrm{Rh}-\mathrm{P}$ catalysts was observed at higher reduction temperatures compared with other catalysts. This trend was the same as the formation of $\mathrm{Rh}_{2} \mathrm{P}$ observed in XRD patterns and TPR spectra, as shown in Figs. 2 and 3 ((ii) and (v)). These results indicate that the TOF of $\mathrm{Rh}-\mathrm{P}$ catalysts was remarkably enhanced by the $\mathrm{Rh}_{2} \mathrm{P}$ formation. The order of TOF for $\mathrm{Rh}-\mathrm{P}$ catalysts was as follows; $\mathrm{TiO}_{2}>\mathrm{ZrO}_{2}>\mathrm{Al}_{2} \mathrm{O}_{3}>\mathrm{SiO}_{2}>$ $\mathrm{MgO}$. $\mathrm{TiO}_{2}$ is sulfided with $10 \% \mathrm{H}_{2} \mathrm{~S}-\mathrm{H}_{2}$ and sulfided $\mathrm{TiO}_{2}$ acts as promoter for Mo-based HDS catalyst ${ }^{44)}$. Furthermore, sulfided $\mathrm{TiO}_{2}$ is involved in the active phase of the HDS reaction ${ }^{45}$. In the HDS reaction, the reduced $\mathrm{TiO}_{x}$ species may react with $\mathrm{H}_{2} \mathrm{~S}$ to form partially sulfided $\mathrm{TiO}_{2}$ species $\left(\mathrm{TiO}_{x} \mathrm{~S}_{y}\right)$, and $\mathrm{TiO}_{x} \mathrm{~S}_{y}$ also acts as promoter to enhance the TOF of $\mathrm{Rh}-\mathrm{P}$ catalyst. Thus, the remarkably high TOF of $\mathrm{Rh}-\mathrm{P} / \mathrm{TiO}_{2}$ catalyst can be explained by the promotion effect of $\mathrm{TiO}_{x} \mathrm{~S}_{y}$. Furthermore, the high TOF of $\mathrm{Rh}-\mathrm{P} / \mathrm{ZrO}_{2}$ catalyst is explained by the remarkably larger crystalline size of $\mathrm{Rh}_{2} \mathrm{P}$ compared with other $\mathrm{Rh}-\mathrm{P}$ catalysts (Table 5) as well as $\mathrm{Rh} / \mathrm{ZrO}_{2}$ catalyst. However, the TOF of $\mathrm{Rh}-\mathrm{P} /$ $\mathrm{ZrO}_{2}$ catalyst did not decrease with higher reduction temperature. The basic properties of $\mathrm{PO}_{4}{ }^{3-} / \mathrm{ZrO}_{2}$ are decreased by reaction of the basic sites on $\mathrm{ZrO}_{2}$ with
$\mathrm{PO}_{4}{ }^{3-}$ to form acidic sites ${ }^{46)}$. Furthermore, the TPR spectra of $\mathrm{Rh}-\mathrm{P} / \mathrm{ZrO}_{2}$ (Fig. 3 (v), (c)) showed that reduction of $\mathrm{PO}_{4}{ }^{3-}$ occurred at higher temperatures (above $600{ }^{\circ} \mathrm{C}$ ). Thus, since the remaining $\mathrm{PO}_{4}{ }^{3-}$ prevented the formation of strong basic sites, the TOF of $\mathrm{Rh}-\mathrm{P} /$ $\mathrm{ZrO}_{2}$ catalyst was not decreased by higher reduction temperature. On the other hand, formation of $\mathrm{Rh}_{2} \mathrm{P}$ enhances the TOF of $\mathrm{Rh}-\mathrm{P} / \mathrm{ZrO}_{2}$ catalyst reduced at high reduction temperature (above $600{ }^{\circ} \mathrm{C}$ ), as shown in Fig. 8 (ii). Regardless of the similar crystalline size of $\mathrm{Rh}_{2} \mathrm{P}$, the TOFs of $\mathrm{Rh}-\mathrm{P}$ catalyst supported on $\mathrm{Al}_{2} \mathrm{O}_{3}$ and $\mathrm{SiO}_{2}$ were higher than that supported on $\mathrm{MgO}$, because the basic properties of $\mathrm{MgO}$ would lead to low sulfur tolerance of the $\mathrm{Rh}_{2} \mathrm{P}$ catalyst.

\section{Conclusions}

$\mathrm{Rh}_{2} \mathrm{P}$ was formed on $\mathrm{MO}_{x}$ support after reduction but differences in the formation temperatures of $\mathrm{Rh}_{2} \mathrm{P}$ were observed by changing the $\mathrm{MO}_{x}$ support. Furthermore, the HDS activities of the supported $\mathrm{Rh}-\mathrm{P}$ catalysts strongly changed with higher reduction temperature. $\mathrm{Rh}-\mathrm{P}$ catalysts showed higher HDS activity than $\mathrm{Rh}$ catalysts and the order of HDS activities of $\mathrm{Rh}-\mathrm{P} / \mathrm{MO}_{x}$ catalysts reduced at optimal temperatures was $\mathrm{SiO}_{2} \sim$ $\mathrm{TiO}_{2} \sim \mathrm{Al}_{2} \mathrm{O}_{3}>\mathrm{MgO}>\mathrm{ZrO}_{2}$. On the other hand, the order of TOF of supported $\mathrm{Rh}-\mathrm{P}$ catalysts calculated from $\mathrm{CO}$ uptake was $\mathrm{TiO}_{2}>\mathrm{ZrO}_{2}>\mathrm{Al}_{2} \mathrm{O}_{3}>\mathrm{SiO}_{2}>$ $\mathrm{MgO}$, and this order disagreed with that of thiophene conversion. The high TOF of $\mathrm{Rh}-\mathrm{P} / \mathrm{TiO}_{2}$ catalyst may be explained by formation of partially sulfided $\mathrm{TiO}_{2}$. The low TOF of $\mathrm{Rh}-\mathrm{P} / \mathrm{MgO}$ catalyst was attributed to the basicity of the support with low sulfur tolerance.

\section{Acknowledgment}

We would like to thank Nippon Aerosil Co., Ltd. for supplying the silica gel. This work was supported by a Grant-in-Aid for Young Scientists (B), Japan (21750158).

\section{References}

1) Saih, Y., Nagata, M., Funamoto, T., Masuyama, Y., Segawa, K., Appl. Catal. A: General, 295, 11 (2005).

2) Okamoto, Y., Ochiai, K., Kawano, M., Kubota, T., J. Catal., 222, 143 (2004).

3) Okamoto, Y., Catal. Today, 132, 9 (2008)

4) Shimizu, T., Hiroshima, K., Honma, T., Mochizuki, T., Yamada, M., Catal. Today, 45, 271 (1998).

5) Sun, M., Nicosia, D., Prins, R., Catal. Today, 86, 173 (2003).

6) Rinaldi, N., Usman, Al-Dalama, K., Kubota, T., Okamoto, Y., Appl. Catal. A: General, 360, 130 (2009).

7) Fujikawa, T., Catal. Surv. Asia, 10, 89 (2006).

8) Usman, Yamamoto, T., Kubota, T., Okamoto, Y., Appl. Catal. A: General, 328, 219 (2007).

9) Sugioka, M., Kurosaka, T., J. Jpn. Petrol. Inst., 45, (6), 342 (2002).

10) Ishihara, A., Dumeignil, F., Lee, J., Mitsuhashi, K., Qian, E. W., 
Kabe, T., Appl. Catal. A: General, 289, 163 (2005).

11) Kanda, Y., Kobayashi, T., Uemichi, Y., Namba, S., Sugioka, M., Appl. Catal. A: General, 308, 111 (2006).

12) Niquille-Röthlisberger, A., Prins, R., Catal. Today, 123, 198 (2007).

13) Kanda, Y., Seino, A., Kobayashi, T., Uemichi, Y., Sugioka, M., J. Jpn. Petrol. Inst., 52, (2), 42 (2009).

14) Venezia, A. M., Murania, R., La Parola, V., Pawelec, B., Fierro, J. L. G., Appl. Catal. A: General, 383, 211 (2010).

15) Aegerter, P. A., Quigley, W. W. C., Simpson, G. J., Ziegler, D. D., Logan, J. W., McCrea, K. R., Glazier, S., Bussell, M. E., J. Catal., 164, 109 (1996).

16) Dhandapani, B., Clair, T. St., Oyama, S. T., Appl. Catal. A: General, 168, 219 (1998).

17) Lewandowski, M., Szymańska-Kolasa, A., Da Costa, P., Sayag, C., Catal. Today, 119, 31 (2007).

18) Nagai, M., Appl. Catal. A: General, 322, 178 (2007).

19) Sawhill, S. J., Philips, D. C., Bussell, M. E., J. Catal., 215, 208 (2003).

20) Wang, A., Ruan, L., Teng, Y., Li, X., Lu, M., Rena, J., Wanga, Y., Hu, Y., J. Catal., 229, 314 (2005).

21) Yang, S., Liang, C., Prins, R., J. Catal., 237, 118 (2006).

22) Sawhill, S. J., Layman, K. A., Van Wyk, D. R., Engelhard, M. H., Wang, C., Bussell, M. E., J. Catal., 231, 300 (2005).

23) Lee, Y. K., Oyama, S. T., Appl. Catal. A: General, 322, 191 (2007).

24) Oyama, S. T., Lee, Y. K., J. Catal., 258, 393 (2008).

25) Clark, P., Wang, X., Oyama, S. T., J. Catal., 207, 256 (2002).

26) Phillips, D. C., Sawhill, S. J., Self, R., Bussell, M. E., J. Catal., 207, 266 (2002).

27) Clark, P. A., Oyama, S. T., J. Catal., 218, 78 (2003).

28) Montesinos-Castellanos, A., Zepeda, T. A., Pawelec, B., Lima, E., Fierro, J. L. G., Olivas, A., de los Reyes, H., J. A., Appl. Catal. A: General, 334, 330 (2008).

29) Kanda, Y., Temma, C., Nakata, K., Sugioka, M., Uemichi, Y., Appl. Catal. A: General, 386, 171 (2010).

30) Hayes, J. R., Bowker, R. H., Gaudette, A. F., Smith, M. C.,
Moak, C. E., Nam, C. Y., Pratum, T. K., Bussell, M. E., J. Catal., 276, 249 (2010).

31) Mochida, I., Choi, K. H., J. Jpn. Petrol. Inst., 47, (3), 145 (2004).

32) Yasuda, H., Sato, T., Yoshimura, Y., Catal. Today, 50, 63 (1999).

33) Simon, L. J., Ommen, J. G. V., Jentys, A., Lecher, J. A., Catal. Today, 73, 105 (2002).

34) Barrio, V. L., Arias, P. L., Cambra, J. F., Güemez, M. B., Pawelec, B., Fierro, J. L. G., Catal. Commun., 5, 173 (2004).

35) Ruckensteinl, E., Wang, H. Y., J. Catal., 187, 151 (1999).

36) Sweeney, C. M., Stamm, K. L., Brock, S. L., J. Alloys Comp., 448, 122 (2008).

37) Matsui, T., Harada, M., Ichihashi, Y., Bando, K. K., Matsubayashi, N., Toba, M., Yoshimura, Y., Appl. Catal. A: General, 286, 249 (2005).

38) Cavanagh, R. R., Yates Jr., J. T., J. Chem. Phys., 74, 4150 (1981).

39) Tauster, S. J., Acc. Chem. Res., 20, 389 (1987).

40) Bernal, S., Calvino, J. J., Cauqui, M. A., Gatica, J. M., López Cartes, C., Pérez Omil, J. A., Pintado, J. M., Catal. Today, 77, 385 (2003).

41) Matsuhashi, H., Nishiyama, S., Miura, H., Eguchi, K., Hasegawa, K., Iizuka, Y., Igarashi, A., Katada, N., Kobayashi, J., Kubota, T., Mori, T., Nakai, K., Okazaki, N., Sugioka, M., Umeki, T., Yazawa, Y., Lu, D., Appl. Catal. A: General, 272, 329 (2004).

42) Angeles Aramendía, M., Victoriano Boráu, Jiménez, C., Marinas, J. M., Porras, A., Unbano, F. J., J. Chem. Soc., Faraday Trans., 93, (7), 1431 (1997).

43) Tomishige, K., Ikeda, Y., Sakaihori, T., Fujimoto, K., J. Catal., 192, 355 (2000).

44) Coulier, L., van Veen, J. A. R., Niemantsverdriet, J. W., Catal. Lett., 79, 149 (2002).

45) Wang, D., Qian, W., Ishihara, A., Kabe, T., J. Catal., 203, 322 (2001).

46) Pattnayak, P. K., Parida, K. M., J. Colloid Interface Sci., 226, 340 (2000). 
要旨

\section{リン化ロジウム触媒の活性点形成と水素化脱硫活性に与える担体の影響}

神田 康晴 ${ }^{\dagger 1}$, , 中田 圭輔 ${ }^{\dagger 2}$, 天満 千智 ${ }^{\dagger 3}$, 杉岡 正敏 ${ }^{\dagger 4)}$, 上道 芳夫 ${ }^{\dagger 11}$

†1) 室蘭工業大学大学院工学研究科くらし環境系領域応用化学ユニット, 050-8585 北海道室蘭市水元町27-1

†2) 室蘭工業大学大学院工学研究科応用理化学系専攻, 050-8585 北海道室蘭市水元町27-1

†3) 室蘭工業大学大学院工学研究科応用化学専攻, 050-8585 北海道室蘭市水元町27-1

†4) 室蘭工業大学大学院工学研究科もの創造系領域航空宇宙工学工ニット, 050-8585 北海道室蘭市水元町27-1

リン化ロジウム $\left(\mathrm{Rh}_{2} \mathrm{P}\right)$ 触媒の活性点形成とその水素化脱 硫（HDS）活性に対する担体の影響について検討した。担体に は金属酸化物（ $\mathrm{MO}_{x}: \mathrm{SiO}_{2}, \mathrm{Al}_{2} \mathrm{O}_{3}, \mathrm{TiO}_{2}, \mathrm{MgO}$ および $\left.\mathrm{ZrO}_{2}\right)$ を用いた。いずれの担体の場合でも担持ロジウムーリン $(\mathrm{Rh}-\mathrm{P})$ 触媒を水素還元すると $\mathrm{Rh}_{2} \mathrm{P}$ が生成した。一方, $\mathrm{Rh}_{2} \mathrm{P}$ の生成温 度は担体により異なった。この Rh-P 触媒の HDS 活性は還元 温度によって大きく変化した。最適な温度で還元した Rh-P/ $\mathrm{MO}_{x}$ 触媒の $\mathrm{HDS}$ 活性の序列は $\mathrm{SiO}_{2} \sim \mathrm{TiO}_{2} \sim \mathrm{Al}_{2} \mathrm{O}_{3}>\mathrm{MgO}>$
$\mathrm{ZrO}_{2}$ となった。また，還元温度を上昇させると $\mathrm{Rh}-\mathrm{P} / \mathrm{MO}_{x}$ 触媒 の TOF は増加し，これは $\mathrm{Rh}_{2} \mathrm{P}$ が生成したためであることが分 かった。 Rh-P/MO $x$ 触媒の $\mathrm{TOF}$ の序列は $\mathrm{TiO}_{2}>\mathrm{ZrO}_{2}>\mathrm{Al}_{2} \mathrm{O}_{3}>$ $\mathrm{SiO}_{2}>\mathrm{MgO}$ となり, これはチオフェン転化率の序列とは一致 しなかった。 $\mathrm{Rh}-\mathrm{P} / \mathrm{TiO}_{2}$ 触媒が高い $\mathrm{TOF}$ を示した原因としては, 部分的に硫化された $\mathrm{TiO}_{2}$ の生成が挙げられる。一方, $\mathrm{Rh}-\mathrm{P} /$ $\mathrm{MgO}$ 触媒の $\mathrm{TOF}$ が低かったのは, $\mathrm{MgO}$ は塩基性担体であり 耐硫黄性が低かったためと考えられる。 